\title{
Leaf-litter Entomofauna as a Parameter to Evaluate Areas Under Ecological Restoration
}

\author{
Sandra Ciriaco de Cristo $^{1}$ (D), Marcelo Diniz Vitorino ${ }^{2}$ (D), \\ Taise Cristina Plattau Arenhardt ${ }^{3}$ (D), Guilherme Alan Klunk ${ }^{4}$ (D), \\ Eduardo Adenesky Filho ${ }^{2}$ (D), Acacio Geraldo de Carvalho ${ }^{1}$ \\ ${ }^{1}$ Programa de Pós-graduação em Ciências Ambientais e Florestais, \\ Universidade Federal Rural do Rio de Janeiro - UFRRJ, Seropédica/RJ, Brasil \\ ${ }^{2}$ Programa de Pós-graduação em Engenharia Florestal, Departamento de Engenharia Florestal, \\ Universidade Regional de Blumenau - FURB, Blumenau/SC, Brasil \\ ${ }^{3}$ Programa de Pós-graduação em Engenharia Florestal, Universidade Regional de Blumenau - FURB, \\ Blumenau/SC, Brasil \\ ${ }^{4}$ Curso de Engenharia Florestal, Universidade Regional de Blumenau - FURB, Blumenau/SC, Brasil
}

\begin{abstract}
The aim of this study was to characterize the leaf-litter entomofauna in degraded areas under restoration process with different restoration techniques, using the native forest as a reference and ecological indexes as parameters to select bioindicator groups. The study was conducted at "Serra do Itajai" National Park (PNSI). The survey was conducted from winter/2014 to autumn/2016. The characterization of sampled communities was performed using identification, order, families and faunal indexes such as frequency, constancy and dominance. Overall, 11,241 insects from 57 taxonomic groups were collected in pitfall traps. The native forest showed the greatest richness observed. Groups classified as frequent, constant and dominant in all environments were the Formicidae family and Diptera Order. Significant differences were observed in the frequencies of Ptiliidae, Staphylinidae and Cicadellidae families and also Diptera Order. Coleoptera Ptiliidae, Staphylinidae families and Scolytinae subfamily showed potential as bioindicators of environmental quality at PNSI.
\end{abstract}

Keywords: rainforest, environmental indicator, biodiversity, hotspot area, insecta. 


\section{INTRODUCTION}

The Brazilian Atlantic Forest is one of the richest formations of existing biodiversity ecosystems, occupying the fourth place among the 25 hotspots in the world, but it is also the most threatened biome on the planet (Myers et al., 2000), being one of the priorities in global discussions on preservation, environment and strategies for risk management. However, in addition to the need of preserving remnants of the Atlantic Forest, which is already at advanced stage of environmental degradation, large-scale restoration actions of this biome are also necessary, including protected areas. The restoration of degraded ecosystems requires evaluating and monitoring these areas with indicators capable of reporting changes in these environments. The use of organisms as indicators of environmental quality is a good strategy for environment monitoring and has been pointed out as an increasingly effective and less costly tool (Rodrigues \& Gandolfi, 2004). Some evaluation methods include various levels of biological organization and use different possibilities of temporal response scales such as minutes, hours, days, years and even decades (Louzada \& Zanetti, 2013). The results of these studies allow us inferring about the quality of the environment or the effect of some stressor agent on living organisms (Louzada \& Zanetti 2013), aiding in the recovery strategies of a certain environment that requires intervention.

The use of insects as biological indicators has been suggested as an effective way to investigate the extent in which the Atlantic Forest Biome is being affected by anthropic activities (Freitas et al., 2003). Insects have their importance recognized by their involvement in several processes and ecological functions that take place in an ecosystem. These organisms also provide important ecosystem services (Neves et al., 2011), with emphasis on the leaf-litter entomofauna, which participates in several ecological processes, mainly plant material fragmentation and redistribution of particles. In addition, it is also the food base for other local organisms (Louzada, 2009).

In this way, the characterization of the leaf-litter entomofauna during the ecosystem restoration process carried out using different nucleation techniques is a proposal that requires the knowledge of parameters to facilitate the interpretation and evaluation of restoration in areas of the "Serra do Itajaí" National Park, state of Santa Catarina. Thus, the hypothesis of this work was that the leaf-litter entomofauna composition is influenced by vegetal richness and by the nucleation techniques used. This study aimed to characterize the leaf-litter entomofauna present in a forest at an advanced successional stage using ecological indexes as parameters and to compare it to areas under ecological restoration process to determine bioindicator groups.

\section{MATERIAL AND METHODS}

\subsection{Sampled areas}

The study was carried out at "Serra do Itajai" National Park (PNSI), an Integral Protection Conservation Unit, located at "Vale do Itajai" region, state of Santa Catarina. The study area is in the locality known as "Faxinal do Bepe", presenting high degree of anthropization due to the conversion from native forest to pasture and agriculture areas for 40 years, Brasil (2009), and since 2014, the area has undergone ecological restoration techniques, using different nucleation techniques (Figure 1), and planting of native seedlings.

To carry out this study, five areas were selected: native forest area, UTM (22J 6790707000698 ), natural regeneration at early successional stage (22J 678854 7000477), and 3 areas classified as pasture, where the following nucleation techniques were used: soil roughness (22J 6775376999504 ), artificial perches (22J 677702 6999104) and brushwood transposition (22J 677798 6999301).

The vegetation characterization in the different areas under study was performed through a phytosociological survey. For this, the quadrant method was used in the initial regeneration, soil roughness and artificial perch techniques according to Cottam \& Curtis (1956), totaling 25 sample points for each unit. In the native forest, $6410 \mathrm{~m} \mathrm{x} 30 \mathrm{~m}$ north-south-oriented plots (300 $\mathrm{m} 2)$, and specifically in the area with brushwood transposition, sampling was composed of 15 subunits of 1 square meter each, due to the absence of tree species in this area (Felfili et al., 2011).

The soil roughness technique was applied in a pasture area with 2 hectares and consisted in the creation of relief concavities that increase the micro-habitat variability (Aumond et al., 2012). Each soil roughness 


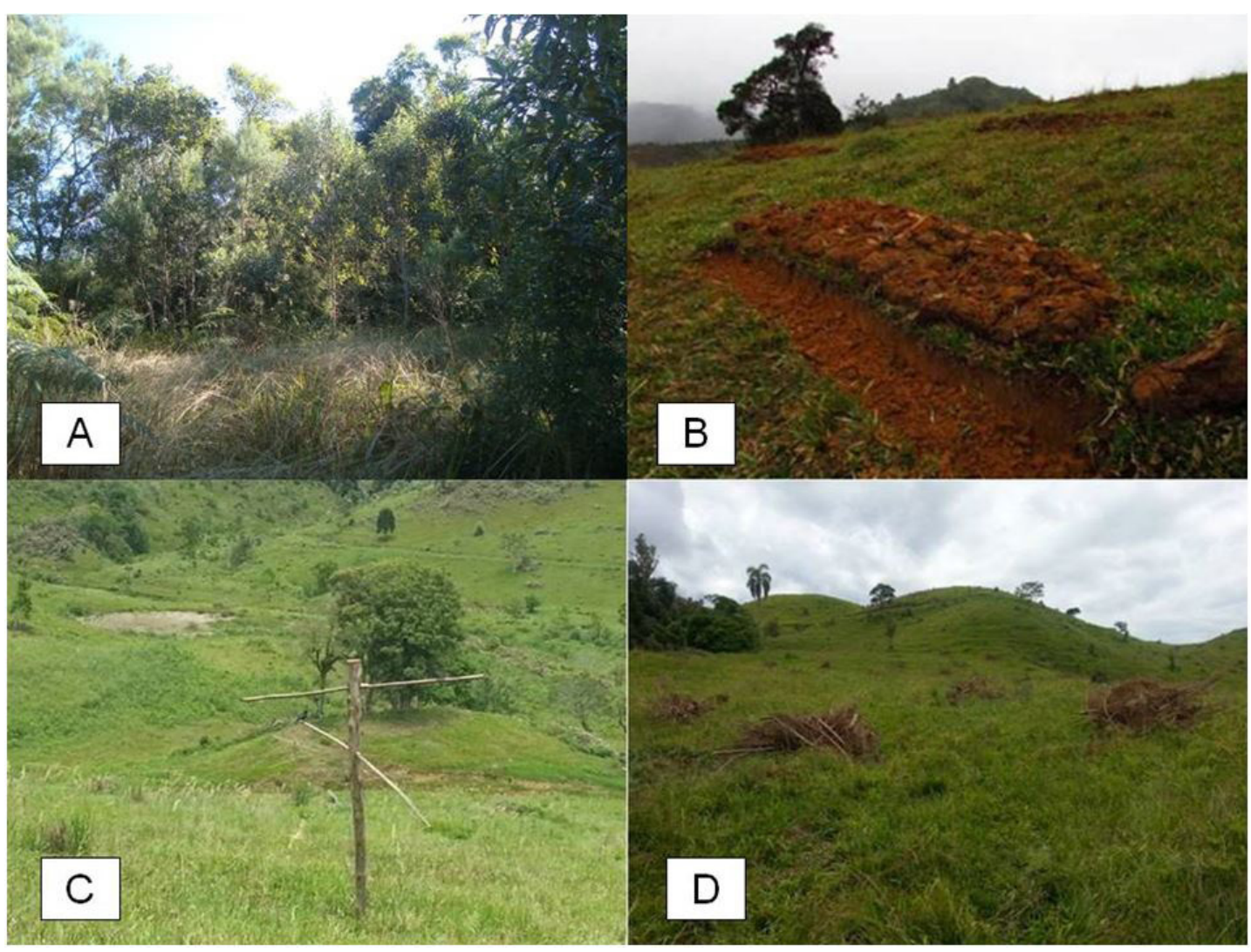

Figure 1. Initial regeneration environment (A) and nucleation techniques: (B) soil roughness, (C) artificial perches and (D) brushwood transposition.

has dimensions of 0.4 meters in depth, 2.0 meters in length and 0.3 meters in width, 4 meters apart, totaling 625 units per hectare. A forest fragment with about 0.5 hectare is bordering this study area.

The nucleation technique of artificial perches was applied in 12-hectare areas of steep pasture. Each perch was made with eucalyptus struts of 3.5 meters in length, buried 0.5 meters into the ground. Bamboos of 1.5 meters in length were introduced at the top, which serve as branches for the landing of birds. Twenty perches per hectare were randomly installed, totaling 240 nucleation points.

The brushwood transposition technique was applied in a 2-hectare pasture area and consisted of the installation of modules composed of plant remains that form nuclei, serving as shelter, nests or for feeding for several species of animals, also forming favorable environments for insect decomposers (Reis et al., 2003). Each module was left on the soil surface and occupies an area of approximately $2 \mathrm{~m} \mathrm{x} 2 \mathrm{~m}\left(4 \mathrm{~m}^{2}\right)$, covering an area of $320 \mathrm{~m}^{2}$ per hectare (3.2\%), with 0.5 to 1.0 meter in height. Eighty modules were installed per hectare, totaling 160 modules, distributed in an equidistant pattern. For module formation, trunks, branches and dry stems of exotic species harvested in PNSI areas were used, mainly of adult Pinus spp individuals without any reproductive organs. All material was dried at the environment before the installation of modules.

\subsection{Leaf-litter entomofauna population survey}

The leaf-litter entomofauna survey was carried out from the winter 2014 to the autumn 2016, totaling 8 collections. Field collections occurred in the second half of the second month of each season. One hundred-meter transect was installed in each sampling area, which remained in the field for three nights, containing five pitfall traps at ground level, filled with water, 70\% 
alcohol and biodegradable detergent, disposed every 20 meters. Transects were installed at different sites within each sampling area from one collection date to another. Climatic data (temperature, relative humidity and precipitation) were obtained from CEOPS/FURB Alert System Operation Center.

\subsection{Data analysis}

The sampled entomofauna was identified at Order and Family levels and its characterization was performed using the following faunistic indexes: relative abundance, constancy and dominance. Relative abundance was calculated according to the frequency distribution and total rate sampled by area according to Brower \& Zar (1984). Constancy (C) was calculated according to equation suggested by Dajoz (1983), and dominance was determined using the limit of dominance (LD) equation proposed by Sakagami \& Laroca (1971). In order to verify data normality of taxonomic groups by collection period and area, the Shapiro-Wilk normality test was applied. The non-parametric Kruskal-Wallis test (5\% significance) and post-hoc Mann Whitney test with Bonferroni's correction $(\mathrm{P}<0.05)$ was also applied, and data obtained in the native forest were used as reference for all comparisons. Analyses were performed using the PAST software, version 3.04 (Hammer et al., 2001).

Rabinowitz et al. (1986) proposed a system for the classification of vegetal rarity into 7 forms, considering the geographic distribution of species, preference for habitats and population size. Caiafa \& Martins (2010) applied the Rabinowitz system to the Atlantic Dense Ombrophylous Forest of southern Brazil, which was used to classify the vegetation of areas sampled in this study.

\section{RESULTS AND DISCUSSION}

\subsection{Flora characterization}

The vegetation present in the sampling areas was characterized by the identification of the most density species, rarity and ecological groups. The native forest belongs to the Ombrophylous Dense Montana Forest, characterized in this study by the presence of 167 tree species, with great diversity among ecological groups and much lower species density in relation to the other areas, proving its greater heterogeneity and vegetal diversity, in addition to the presence of successional process. There is also the presence of rare species in five rarity forms from seven proposed by Rabinowitz et al. (1986) with very low density and importance value.

Comparing native forest with the other areas, it is clear that the reference is more likely to present more complex leaf-litter system and conditions to shelter different groups of organisms due to the abundance and richness of trees. The rarity forms found in this area show all characteristics used to determine rarity forms such as eurytopic species (wide geographic distribution), stenotopic species (restricted geographic distribution), euryoecious species (various types of habitats), stenoecious species (unique habitat), species with locally abundant populations, locally scarce species and species present only in a single sample. The rarity forms proposed by Rabinowitz et al. (1986) and adopted in this study describe the seven rarity forms as follow: Rarity form 1 - locally scarce eurytopic and euryoecious species. Rarity form 2 - species with wide geographic distribution with abundant populations occurring in a single habitat. Rarity form 3 - species with wide geographic distribution in a single habitat with scarce populations. Rarity form 4 - locally abundant stenotopic and euryoecious species. Rarity form 5 - locally scarce stenotopic and euryoecious species. Rarity form 6 - locally abundant stenotopic and stenoecious species. Rarity form 7 - stenotopic and stenoecious species with locally scarce population, being the most restrictive form. The presence of 31 species distributed into five rarity forms and rarity form 4 being the most abundant among them shows that the native forest presents species associated with geographical and altitudinal local aspects. Furthermore, the presence of many species characterized as shade tolerant and light demanders prove the presence of successional phases.

The initial regeneration areas present a total number of very small species $(n=16)$ compared with the native forest, but the ecological group of pioneers (Table 1) deserves attention due to their high density. The following species showed the highest densities: Vernonanthura discolor (Spreng.) H.Rob. (Common), Piptocarpha regnellii (Sch.Bip.) Cabrera (rarity form 7), Myrsine coriacea (Sw.) R.Br. Ex Roem. \& Schult. (Common), Piptocarpha axillaris (Less.) 


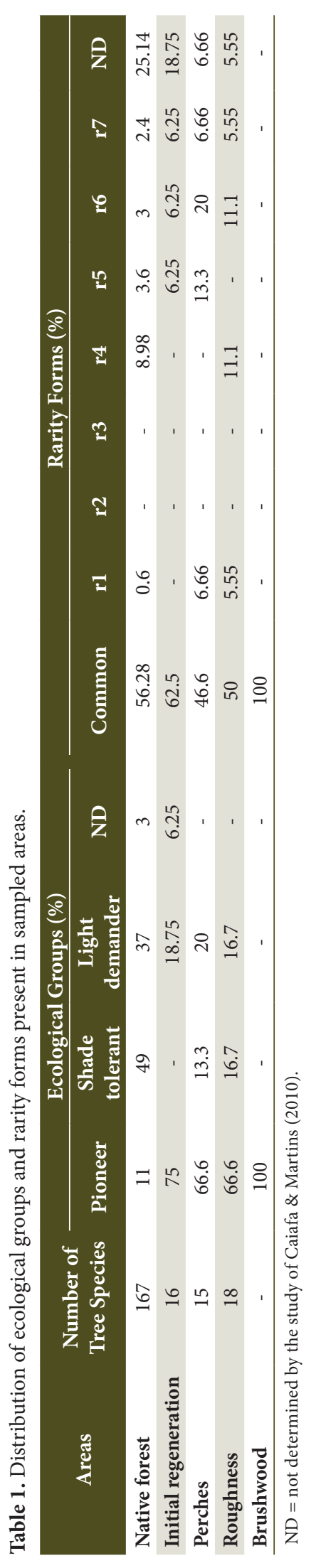


Baker (Common), Piptocarpha angustifolia Dusen ex Malme (Common) and Baccharis semiserrata DC. (rarity form 6). This area presented at least one species for each rarity form as follows (r5, r6 and r7) and no shade-tolerant species were found, demonstrating that only the initial successional phase is established.

Areas sampled with the artificial perches technique presented a total of 15 species from which the ecological group of pioneers were the densest, with 4 species standing out due to their high density: Vernonanthura discolor (Common), Piptocarpha regnellii (rarity form 7), Myrsine coriacea (Common) and Piptocarpha axillaris (Common). This area presents some similarities with initial regeneration areas such as the presence of high-density species, total number of species sampled and the presence of light demanding species. The same behavior was observed in areas with soil roughness, showing a total of 18 species and the ecological group of pioneers with 4 species standing out in terms of density: V. discolor (Common), P. regnellii (rarity form 7), Baccharis sp. (Common) and M. coriacea (Common).

Areas sampled with brushwood presented herbaceous species only, $100 \%$ pioneers, with the Poaceae family dominating the environment cover, with the presence of sparse Asteraceae and Cyperaceae individuals, the latter family being conditioned to humid lowland environments (hydromorphic soils). The main genera were Urochloa sp. (Poaceae), Baccharis sp., Senecio sp. (Asteraceae) and Cyperus sp. (Cyperaceae).

\subsection{Entomofauna characterization}

From the winter 2014 to the autumn 2016, 11,241 insects were collected with pitfall traps in the sampled areas. The collected taxa belong to 59 taxonomic groups, being 58 families, plus the Diptera order. The 58 families belong to 4 orders, with Coleoptera being the most representative order with 27 families, followed by Hemiptera $(n=18)$, Hymenoptera $(n=7)$ and Orthoptera $(n=4)$. Similar results were found by Carvalho \& Pereira (2012) and Lopes (2015) in studies carried out in the Brazilian Atlantic Forest, also using pitfall traps, where Coleoptera had the highest family richness $(n=12)$ and was also the most representative, respectively. The high number of coleopteran individuals sampled in areas of this study demonstrated that this group has distribution in different types of environments.
Among sampled areas, the forest environment presented the highest richness, presenting 40 taxonomic groups, followed by the initial regeneration environment with 38 taxonomic groups. In areas with nucleation techniques, soil roughness was the richest with 34 groups, followed by artificial perches $(\mathrm{n}=31)$ and transposition of brushwood $(n=21)$. The statistical analysis showed significant difference in the frequencies of taxa collected in the study areas (Table 2), mainly between native forest and initial regeneration areas in relation to the nucleation areas. The high flora diversity in the case of native forest areas and the high density of some individuals of the vegetation, in the case of areas of initial regeneration, influenced the entomofauna abundance. Relative abundance was determined for all taxa in all environments under study, but only those with relative abundance $>1 \%$ (Table 3 ) were listed.

Groups classified as constant and dominant in all environments were Formicidae family and Diptera order, but both were not evaluated in this study due to the high number of different types of functional groups present in these groups and the need for taxonomic identification at specific level. The Coleoptera Ptiliidae family showed high abundance in forest areas and initial regeneration, similarly to Scolytinae sub-familiy and Staphylinidae family in relation to areas under restoration with nucleation techniques.

The proportional evaluation of the presence of each taxa in relation to the sample areas (Figure 2) showed that the Ptiliidae family occurred predominantly in native forest areas, which presented greater plant diversity and also in areas of initial regeneration, which presented the highest density of arboreal individuals.

Table 2. Total frequency and maximum and minimum values of individuals obtained by collections peformed in each area.

\begin{tabular}{cccc}
\multirow{2}{*}{ Area } & Total of & \multicolumn{2}{c}{ Values } \\
\cline { 3 - 4 } & individuals & Maximum & Minimum \\
\hline Forest & $3,825 \mathrm{a}$ & 1,284 & 118 \\
Regeneration & $2,589 \mathrm{a}$ & 544 & 101 \\
\hline Roughness & $1,079 \mathrm{ab}$ & 277 & 75 \\
\hline Brushwood & $2,198 \mathrm{ab}$ & 470 & 181 \\
\hline Perches & $1,550 \mathrm{ab}$ & 373 & 79 \\
\hline
\end{tabular}

There are no statistical differences among values followed by the same letter in the same column, by the KrusKall Wallis test $(\mathrm{P}<0,05)$ post-hoc Mann Whitney with Bonferroni $(\mathrm{P}<0.05)$ correction. 
Table 3. Total frequency of taxa classified as constant and relative abundance (Ab) higher than $1 \%$ for each area.

\begin{tabular}{|c|c|c|c|c|c|c|c|c|c|c|}
\hline \multirow{2}{*}{ Taxa } & \multicolumn{2}{|c|}{ Forest } & \multicolumn{2}{|c|}{ Regeneration } & \multicolumn{2}{|c|}{ Brushwood } & \multicolumn{2}{|c|}{ Roughness } & \multicolumn{2}{|c|}{ Perches } \\
\hline & Total & $\mathbf{A b}$ & Total & $\mathbf{A b}$ & Total & $\mathbf{A b}$ & Total & $\mathbf{A b}$ & Total & $\mathbf{A b}$ \\
\hline Ptiliidae & $1,347 \mathrm{a}$ & 35.21 & $343 \mathrm{ab}$ & 13.24 & $16 \mathrm{~b}$ & - & $16 \mathrm{~b}$ & 1.48 & $10 \mathrm{~b}$ & - \\
\hline Formicidae & $467 \mathrm{a}$ & 12.20 & $640 \mathrm{a}$ & 24.71 & $1,326 a$ & 60.32 & $434 \mathrm{a}$ & 40.22 & $856 a$ & 55.22 \\
\hline Diptera & $941 \mathrm{a}$ & 24.60 & $740 a$ & 28.58 & $521 \mathrm{a}$ & 23.70 & $236 b$ & 21.87 & $394 b$ & 25.41 \\
\hline Staphylinidae & $360 \mathrm{a}$ & 9.41 & $392 \mathrm{ab}$ & 15.14 & $45 b$ & - & $47 b$ & 4.35 & $68 \mathrm{~b}$ & 4.38 \\
\hline Cicadellidae & $4 \mathrm{a}$ & - & $34 \mathrm{a}$ & - & $88 \mathrm{~b}$ & 4 & $50 \mathrm{a}$ & 4.63 & $56 a$ & 3.61 \\
\hline Cercopidae & - & - & $19 \mathrm{a}$ & - & $32 \mathrm{a}$ & 1.45 & $35 \mathrm{a}$ & 3.24 & $10 \mathrm{a}$ & - \\
\hline Scarabaeidae & $39 a$ & 1.01 & $27 \mathrm{a}$ & 1.04 & - & - & - & - & $03 a$ & - \\
\hline Aphididae & - & - & $12 \mathrm{a}$ & - & $50 \mathrm{a}$ & 2.27 & $37 \mathrm{a}$ & 3.42 & $39 a$ & 2.51 \\
\hline Chalcidoidea & $47 a$ & 1.22 & $33 a$ & 1.27 & $36 a$ & 1.63 & $53 a$ & 4.91 & $33 a$ & 2.12 \\
\hline Scolytinae & $467 a$ & 12.2 & $230 \mathrm{a}$ & 8.88 & $27 \mathrm{a}$ & - & $22 \mathrm{a}$ & 2.03 & $17 \mathrm{a}$ & 1.09 \\
\hline
\end{tabular}

There are no statistical differences among values followed by the same letter in the same column by the KrusKall Wallis test $(\mathrm{P}<0,05)$ post-hoc Mann Whitney with Bonferroni $(\mathrm{P}<0.05)$ correction - forest as reference.

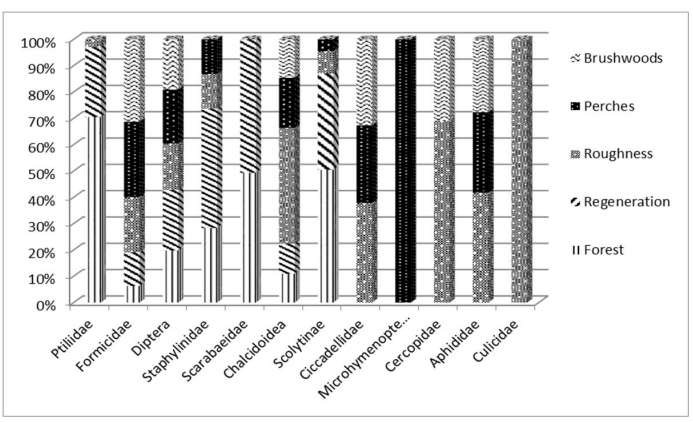

Figure 2. Proportion percentage of main taxa frequency $(\mathrm{Ab}>1 \%)$ in the different study areas.

The analysis with the frequency values showed significant differences between native forest areas and areas under restoration (Kruskal-Wallis $\mathrm{p}<0.05$ ), but there was no significant difference between native forest and areas of initial regeneration or between regeneration and areas under restoration (Table 3). Thus, it was evidenced that the Ptiliidae family was influenced by the greater richness of arboreal species present in forest areas, as well as by the density, since it was also present in the areas of natural regeneration. Insects of the Ptiliidae family were $100 \%$ constant in forest areas, being dominant and more frequent in the spring 2015. Relative abundance was $35.21 \%$ and it did not correlate significantly with any of the meteorological variables tested in the forest environment. In areas of initial regeneration, the Ptiliidae family was dominant and the highest frequency was observed in the spring 2015, not being sampled in the winter 2014. Relative abundance was $13.24 \%$, however, it showed positive correlation with temperature, differently from the forest environment, the initial regeneration is more susceptible to temperature variations at leaf-litter level due to the lower abundance and diversity of plant species, in addition to the absence of various strata present in the forest environment. In all other areas (brushwood, perches and roughness), these insects showed no constancy, frequency and dominance. The Ptiliidae family showed greater affinity and frequency with the forest area when compared to the other environments under study, and a total of 1,347 individuals were sampled. In the initial regeneration, 343 insects were verified during the study period. In soil roughness technique and in brushwood transposition, 16 individuals were sampled in each area, and in areas with artificial perches, a total of 10 insects from this family were collected.

In similar studies with Coleoptera fauna surveyed in a park in the state of Paraná, Marinoni \& Ganho (2003) found the highest concentration of the Ptiliidae family in forest areas. According to the authors, this family was the most sensitive to environmental degradation due to its fungivorous feeding habit, inhabiting places where there is presence of decomposing organic matter, usually feeding on fungus spores developing on the leaf-litter surface (Casari \& Ide, 2012). Thus, due to their extreme specialization and fidelity to feeding habits, insects of this family have ecological requirements that qualify them as indicators of the quality of natural environments, and therefore, their abundance, frequency and constancy monitored in all other areas of this study are the parameters to evaluate the environmental responses during the restoration 
process, that is, the positive influence of the restoration techniques on soil, flora and fauna interactions.

The area where the soil roughness technique was applied among the restoration techniques was the richest $(n=37)$, and among the main groups of relative abundance (Table 3), only the Scarabaeidae family and Microhymenoptera were not presented compared to forest and perch areas, respectively. On the other hand, the presence of the forest fragment next to this area seems to be influencing the natural regeneration composition, in addition to the effect of the technique itself, since the number of tree species classified as rare (44.45\%) and belonging to groups (33.2\%) was high in relation to the total recorded species. According to Louzada \& Zanetti (2013), the richness of taxonomic groups of terrestrial invertebrates tends to increase as the processes of ecological succession evolve.

In pasture environments, the taxonomic richness is usually low due to the high disturbance observed in these environments and the low plant diversity directly influences this parameter. In this case, it is not possible to affirm if the relative abundance of the Ptiliidae family in this area would be a consequence of the nucleation technique or the influence of the fragment present in the border of the area. To clarify, the analysis of the other groups shows that the area, although with presence of rare tree species and varied ecological groups, showed entomofauna components characteristic of areas with the presence of grasses and herbaceous species, such as the Cicadellidae, Cercopidae and Aphididae families, showing that the area does not yet have characteristics of vegetal structure sufficient to attract Ptiliidae individuals and, therefore, their presence was due to the influence of the nearby forest fragment.

Insects of the Scolytinae sub-family were frequent, dominant and constant only on native forest environment and in the initial regeneration phase. In forest areas, the relative abundance was $12.2 \%$ and the higher frequency occurred in the spring 2014. These insects did not significantly correlate with any meteorological variable tested. The forest was the environment with the highest concentration of insects of this subfamily (Figure 2), which can be explained, as they depend on forest species to develop. According to Wood (2007), these insects commonly selected broken trees as hosts; however, live trees or the base of shrubs are also used. Gonçalves et al. (2014) found that the Scolytinae sub-family was the most abundant group (43.07\%) in the Atlantic Forest natural environment in relation to other coleopteran families found. In this study, Scolytinae showed population peak related to the spring period. Beetles from the Staphylinidae family were constant and dominant in forest and initial regeneration areas; however, in all other areas with nucleation techniques, they presented low frequency (Figure 2), although they did not show relative abundance higher than $1 \%$ in area with brushwood transposition (Table 3). In forest areas, the highest frequency observed was in the summer 2015 , with relative abundance of $9.41 \%$. In areas with initial regeneration, the highest frequency occurred in the summer 2015 and the relative abundance was $15.14 \%$. There is no significant correlation between these insects and any meteorological variables tested in forest and regeneration environments.

Statistical analysis (Table 3) showed no significant differences between forest and initial regeneration areas regarding the frequencies observed, but forest areas significantly differ from areas under restoration. According to Costa Lima (1952), the Staphylinidae family presents saprophagous, fungivorous and phytophagous habits, but they are usually predators, requiring more conserved and complex habitats (Eisenhauer et al., 2008). According to Freitas et al. (2003), most species of the Staphylinidae family inhabit the leaf-litter environment, being among the most important elements of the soil fauna. The results obtained in this study corroborate the work of Anderson \& Ashe (2000), Garcia et al. (2001) and Fernandes et al. (2011), regarding the importance of this family as a biological indicator, since they were constant and dominant in areas with greater complexity and plant abundance.

Beetles of the Scarabaeidae family were constant only in the forest environment, but with low relative abundance of $1.01 \%$; in the initial regeneration, they were classified as accessories presenting relative abundance of $1.04 \%$ and classified as accidental in areas submitted to artificial perch techniques, not being sampled in areas of roughness and brushwood (Table 3). Although they presented low frequency during the sampling period, the ecological importance of this group cannot be neglected, because they play important roles in the environmental balance. According to Milhomem et al. (2003), some insects of this family are detritivores, aiding in the removal and re-entry of organic matter in the nutrient cycle. There are also pollinator specimens (Casari \& Ide, 2012), and pollination is an essential event for 
the propagation of many species. Due to the great variability in the habits of the Scarabaeoidea superfamily, Otavo et al. (2013), in a study in the Amazon, reported that beetles belonging to this group cannot be used as the only impact bioindicator element. On the other hand, some species of the Scarabaeidae family are also considered biological indicators, and the most studied group is considered bioindicators of the Coleoptera order (Gardner et al., 2008; Vieira \& Mendel, 2002). In this study, beetles of the Scarabaeidae family were found in the most preserved environments, either by the diversity of vegetal groups or by the density of individuals (Figure 2).

Individuals of the Cicadellidae family were constant in all areas, except in native forest areas, where they were classified as accessories, with relative abundance of $0.1 \%$. These insects were dominant in areas with brushwood transposition and soil roughness techniques, with relative abundance of 4.0 and $4.6 \%$, respectively. The highest frequency occurred in the spring 2014, in both areas, with significant difference between the area of brushwood transposition and all other areas (Table 3 ). In the perch area, the relative abundance of these insects was $3.61 \%$, and the highest frequency observed occurred in the autumn 2016. Temperature had significant influence $(\mathrm{R}=-0.91)$ on the occurrence of Cicadellidae individuals, showing strong negative correlation, because with the decrease in temperature, the number of individuals increased. Cicadellidae insects practically did not occur in the forest area, since only four individuals were verified throughout the sampling period. According to Grazia et al. (2012), insects of this family are found in open areas, such as pasture lands or in the presence of shrubs, or in habitats with lower vegetation and, due to their phytophagous habits, they occur more frequently in grassy areas where they feed (Rafael et al., 2012). According to Zanol \& Menezes (1982), grasses are their main host, and this explains their representativeness in areas of restoration techniques, where there are still large amounts of this type of vegetation. However, with the progress of the restoration process, it is expected that these populations will decline since grasses will gradually disappear.

\section{CONCLUSIONS}

The determination of the vegetal composition with phytosociological parameters and rarity forms seems to be useful as a characterization methodology to compare the vegetative evolution of areas under ecological restoration.

The entomofauna identification at family level shows potential to be used for the determination of bioindicators.

Native forest areas significantly differed from areas under restoration process in terms of abundance of individuals captured and the entomofauna composition, serving as parameters for future comparisons.

The Ptiliidae and Staphylinidae families were considered as bioindicators of the environmental quality for native forest areas located at "Faxinal do Bepe" - PNSI.

Climatic variables temperature, precipitation and relative humidity did not significantly influence the presence of groups considered to be bioindicators.

Areas under restoration presented entomofauna typical of anthropic areas.

\section{ACKNOWLEDGEMENTS}

The authors are grateful to Banco Nacional de Desenvolvimento Econômico e Social (BNDES) and the Restaurar Project DEF/PPGEF/FURB for financial and operational support. To Coordenação de Aperfeiçoamento de Pessoal de Nível Superior (CAPES) for the granting of the scholarship to the first author

\section{SUBMISSION STATUS}

Received: 14 mar., 2017

Accepted: 19 jan., 2018

\section{CORRESPONDENCE TO}

\section{Marcelo Diniz Vitorino}

Departamento de Engenharia Florestal, Universidade Regional de Blumenau - FURB, R. São Paulo, 3250, CEP 89030-000, Blumenau, SC, Brasil

e-mail: dinizvitorino@gmail.com

\section{FINANCIAL SUPPORT}

Coordenação de Aperfeiçoamento de Pessoal de Nível Superior, bolsa nível doutorado BNDES, Iniciativa Mata Atlântica, Projeto Restaurar (Grant/Award Number 1157/2012). 


\section{REFERENCES}

Anderson RS, Ashe JS. Leaf leaf-litter inhabiting beetles as surrogates for establishing priorities for conservation of selected tropical montane cloud forest in Honduras, Central America (Coleoptera; Staphylinidae, Curculionidae). Biodiversity and Conservation 2000; 9(5): 617-653. http:// dx.doi.org/10.1023/A:1008937017058.

Aumond JJ, Loch C, Comin JJ. Arbordagem sistêmica e uso de modelos para recuperação de áreas degradadas. Revista Árvore 2012; 36(6): 1099-1118. http://dx.doi. org/10.1590/S0100-67622012000600011.

Brasil. Ministério do Meio Ambiente. Instituto Chico Mendes de Conservação da Biodiversidade. Plano de Manejo do Parque Nacional da Serra do Itajaí. Brasília: Ministério do Meio Ambiente; 2009.

Brower JE, Zar JH. Field and laboratory methods for general ecology. Iowa: Company Publisher Dulrique; 1984.

Caiafa AN, Martins FR. Forms of rarity of tree species in the Southern Brazilian Atlantic rain forest. Biodiversity and Conservation 2010; 19(9): 2597-2618. http://dx.doi. org/10.1007/s10531-010-9861-6.

Carvalho RS, Pereira KS. Entomofauna do solo de Mata primária Atlântica como padrão indicador de qualidade dos ecossistemas. Cruz das Almas: Embrapa Mandioca e Fruticultura; 2012.

Casari SA, Ide S. Coleoptera. In: Rafael JÁ, Melo GAR, Carvalho CJB, Casari AS, Constantino R, editores. Insetos do Brasil: diversidade e taxonomia. Ribeirão Preto: Holos; 2012.

Costa Lima A. Insetos do Brasil. Rio de Janeiro: Escola Nacional de Agronomia; 1952. Série Didática.

Cottam G, Curtis JT. The use of distance measures in phytosociological sampling. Ecology 1956; 37(3): 451-460. http://dx.doi.org/10.2307/1930167.

Dajoz R. Ecologia geral. Petrópolis: Vozes; 1983.

Eisenhauer N, Milcu A, Sabais CW, Scheu S. Animal ecosystem engineers modulate the diversity-invasibility relationship. PLoS One 2008; 3(10): e3489. http://dx.doi. org/10.1371/journal.pone.0003489. PMid:18941521.

Felfili JM, Carvalho FA, Líbano AM, Venturoli F, Pereira BAS, Machado ELM. Análise multivariada: princípios e métodos em estudos de vegetação. In: Felfili JM, Eisenlohr PV, Melo MMRF, Andrade LA, Meira JAA No, editores. Fitossociologia no Brasil: métodos e estudos de casos. Viçosa: UFV; 2011.

Fernandes FS, Alves SS, Santos HF, Rodrigues WC. Staphylinidae e Silphidae (Coleoptera) como potenciais famílias bioindicadoras de qualidade ambiental. Revista Eletrônica TECCEN 2011; 4(3): 17-32. http://dx.doi. org/10.21727/teccen.v4i3.89.
Freitas AVL, Francini RB, Brown KS. Insetos como Indicadores ambientais. In: Cullen L Jr, Rudran R, Valladares CP, organizadores. Métodos de estudos em biologia da conservação e Manejo da Vida Silvestre. Curitiba: UFPR; 2003.

Garcia RI, Armbrecht I, Chacón P. Staphylinidae (Coleoptea): Composición y Mirmecofilia en bosques secos relictuales de Colombia. Folia Entomologica Mexicana 2001; 40(1): 1-10.

Gardner TA, Hernández MIM, Barlow J, Peres CA. Understanding the biodiversity consequences of habitat change: the value of secondary and plantation forests for Neotropical dung beetles. Journal of Applied Ecology 2008; 45(3): 883-893. http://dx.doi.org/10.1111/j.13652664.2008.01454.x.

Gonçalves FG, Carvalho AG, Cardoso WVM, Rodrigues CDS. Coleópteros broqueadores de madeira em ambiente natural de Mata Atlântica e em plantio de eucalipto. Pesquisa Florestal Brasileira 2014; 34(79): 245-250. http:// dx.doi.org/10.4336/2014.pfb.34.79.499.

Grazia J, Cavicchioli R, Wolff VRS, Fernandes JAM, Takiya DM. Hemiptera. In: Rafael JA, Melo GAR, Carvalho CJB, Casari AS, Constantino R, organizadores. Insetos do Brasil: diversidade e taxonomia. Ribeirão Preto: Holos; 2012.

Hammer O, Harper DAT, Rian PD. Past: Palaeonthological statistics software package for education and data analysis: version. 1.37 [online]. 2001 [cited 2017 Mar 14]. Available from: http://palaeo-electronica.org/2001_1/past/issue1_01. htm

Lopes MC. Temporal variation of soil entomofauna from an urban forest fragment in southern Brazil. Revista Acta Scientiarum 2015; 37(1): 51-57.

Louzada J, Zanetti R. Bioindicadores de Impactos Ambientais. In: Moreira FMS, Cares JE, Zanetti R, Sturmer SL. O ecossistema solo. Lavras: UFLA; 2013.

Louzada JNC. Insetos detritívoros. In: Panizzi AR, Parra JRP, editores. Ecologia nutricional de insetos e suas implicações no manejo de pragas. São Paulo: Manole; 2009.

Marinoni RC, Ganho NG. Fauna de Coleoptera no Parque Estadual de Vila Velha, Ponta Grossa, Paraná, Brasil: abundância e riqueza das famílias capturadas através de armadilhas de solo. Revista Brasileira de Zoologia 2003; 20(4): 737-744. http://dx.doi.org/10.1590/S010181752003000400029 .

Milhomem MS, Vaz-de-Mello F, Diniz IR. Técnicas de coleta de besouros copronecrófagos no cerrado. Pesquisa Agropecuária Brasileira 2003; 38(11): 1249-1256. http:// dx.doi.org/10.1590/S0100-204X2003001100001.

Myers N, Mittermeier RA, Mittermeier CG, Fonseca GAB, Kent J. Biodiversity hotsposts for conservation priorities. Nature 2000; 403(6772): 853-858. http://dx.doi. org/10.1038/35002501. PMid:10706275. 
Neves FS, Resende FM, Fernandes GW. Serviços ecossistêmicos fornecidos pelos insetos. MG Biota 2011; 4(4): 32-36.

Otavo SE, Parrado-Rosselli A, Noriega JA. Superfamília Scarabaeoidea (Insecta: Coleoptera) como elemento bioindicador de pertubación antropogénica en un parque nacional amazônico. Revista de Biología Tropical 2013; 61(2): 735-752. http://dx.doi.org/10.15517/rbt.v61i2.11219. PMid:23885586.

Rabinowitz D, Cairns S, Dillon T. Seven forms of rarity and their frequency in the flora of the British Isles. In: Soulé $\mathrm{ME}$, editor. Conservation biology: the science of scarcity and diversity. Massachusetts: Sinauer Associates; 1986.

Rafael JA, Melo GAR, Carvalho CJB, Casari SA, Constantino R. Insetos do Brasil: diversidade e taxonomia. Ribeirão Preto: Holos; 2012.

Reis A, Espíndola MB, Vieira NK. A nucleação como ferramenta para restauração ambiental. In: Anais do Seminário Temático sobre Recuperação de Áreas Degradadas;
2003; São Paulo. São Paulo: Instituto de Botânica; 2003; p. 32-39.

Rodrigues RR, Gandolfi S. Conceitos, tendências e ações para recuperação de florestas ciliares. In: Rodrigues RR, Leitão HF Fo, organizadores. Matas Ciliares: conservação e recuperação. São Paulo: Edusp; 2004.

Sakagami SF, Laroca S. Relative abundance, phenology and flower visits of Apid bees in eastern Paraná, southern Brazil. Koniyu 1971; 39(3): 217-230.

Vieira LM, Mendel SM. Riqueza de artrópodes relacionada à complexidade estrutural da vegetação: uma comparação entre métodos. Campo Grande: Universidade Federal do Mato Grosso do Sul; 2002.

Wood SL. Bark and Ambrosia Beetle of South America (Coleoptera: Scolytidae). Utah: Brigham Young University; 2007.

Zanol KMR, Menezes M. Lista preliminar dos cicadelídeos (Homoptera, Cicadellidae) do Brasil. Iheringia. Série Zoologia 1982; 61: 9-65. 